\title{
CONSEIL INTERNATIONAL DES UNIONS SCIENTIFIQUES
}

Président: Prof. A. von Muralt

Vice-Présidents: Prof. E. Borel

Prof. H. SOLBERG

Secrétaire général: Prof. F. J. M. Stratton

Les Statuts du Conseil Internationale des Unions Scientifiques sont actuellement en voie de révision. 